\title{
Effects of Straw Decomposition DegRee on Leaching and Weed Control EfFicacy of Tebuthiuron and HeXazinONe in GREen SUgARCANE HARVESTING ${ }^{1}$
}

\author{
Efeito do Grau de Decomposição da Palha na Lixiviação e Eficácia de Controle do Tebuthiuron \\ e da Hexazinona no Sistema Cana Crua \\ TONIETO, T.A.P. ${ }^{2}$ and REGITANO, J.B. ${ }^{2}$
}

\begin{abstract}
Green sugarcane harvesting may promote great changes in the dynamics of herbicides in the environment. Our goal was to evaluate the influence of straw decomposition degree on leaching and weed (Ipomoea grandifolia) control efficacy by $\left({ }^{14} \mathrm{C}\right)$ tebuthiuron and hexazinone. The presence of straw on the soil surface affected leaching, mainly for hexazinone (leaching reduced from 37 to $5 \%$ of the applied amount in the presence of straw). Overall, tebuthiuron showed more efficient control of Ipomoea than hexazinone. The straw decomposition degree affected only hexazinone efficacy that was lowest for the least decomposed straw. Further studies are needed to evaluate the effects of sugarcane straw on herbicides dissipation, particularly on volatilization and photolysis, to better predict their efficacy and environmental fate.
\end{abstract}

Keywords: tebuthiuron, hexazinone, straw, decomposition, sugarcane, Ipomoea spp.

RESUMO - O sistema de cana crua promove alterações significativas na dinâmica de herbicidas. Este trabalho avaliou a influência do grau de decomposição da palha na lixiviação e na eficácia de controle da Ipomoea grandifolia pelos herbicidas $\left({ }^{14} \mathrm{C}\right)$ tebuthiuron e hexazinona. A presença de palha na superficie do solo alterou o potencial de lixiviação, principalmente, da hexazinona (reduziu de 37 para 5\% da quantidade aplicada na presença da palha). De modo geral, o tebuthiuron apresentou maior eficácia de controle da Ipomoea do que a hexazinona. O grau de decomposição da palha afetou a eficácia de controle apenas da hexazinona, sendo que esta foi menor na palha menos decomposta. Há necessidade de avaliar o efeito da palhada na dissipação dos herbicidas, sobretudo na volatilização e na fotólise, de forma a predizer adequamente sua eficácia e seu destino ambiental.

Palavras-chave: herbicida, chuva, cana-de-açúcar, Ipomoea spp.

\section{INTRODUCTION}

Sugarcane (Sacharum spp.) was cultivated in approximately 9.9 million ha and yielded around 624 million tones in 2013/2014 (IBGE, 2014; CONAB, 2014). Major changes occurred in the sugarcane industry after the establishment of the Environmental Protocol in 2007, in which straw burning should be eliminated by 2017 (UNICA, 2011). This new process, known as green sugarcane harvesting, leaves $5-20 \mathrm{Mg} \mathrm{ha}^{-1}$ of straw on the soil surface,

Recebido para publicação em 22.3.2014 e aprovado em 20.8.2014.

2 Universidade de São Paulo-ESALQ, Piracicaba-SP, Brazil<thiagotonieto@yahoo.com.br>. 
promoting significant changes in its physical, chemical, and biological properties (Ceddia et al., 1999; Mendoza et al., 2000; Pinheiro et al., 2010). The presence of the straw may compromise herbicide efficacy and environmental behavior, especially for those with higher residual activities since rainwater has to transfer them to the soil (Maciel et al., 2005). For example, a straw layer of $7 \mathrm{Mg}^{\text {ha-1 }}$ can hold up to $200 \mathrm{~L}$ of the sprayed herbicide (Rodrigues, 2005), reducing its leaching and groundwater contamination.

Approximately 43 molecules of herbicides are registered in MAPA for sugarcane, notably tebuthiuron and hexazinone for being largely used. Hexazinone and tebuthiuron belong to the chemical group of triazinones and substituted ureas, with water solubilities $=2.5$ and $33 \mathrm{~g} \mathrm{~L}^{-1}\left(20^{\circ} \mathrm{C}\right) ; \mathrm{K}_{\mathrm{ow}}=1.79$ and 1.36; vapor pressures $=2 \times 10^{-6}$ and $2 \times 10^{7} \mathrm{mmHg}\left(25^{\circ} \mathrm{C}\right)$; $\mathrm{p} K_{\mathrm{a}} \mathrm{s}=1.2$ and 2.2; half-lives $=360-450$ and 10-275 d; and $\mathrm{K}_{\mathrm{d}} \mathrm{s}=0.23-2.58$ and 0.07$1.65 \mathrm{~L} \mathrm{~kg}^{-1}$, respectively. Control efficacy of these herbicides when applied over straw has been studied (Cavenaghi et al., 2007; Maciel et al., 2008); however, reports regarding effects of straw decomposition degree are rare, but it is known that straw decomposition is directly related to water absorption capacity and straw temperature. These factors determine herbicides persistence on the surface. In the field, straw is found in different degrees of decomposition, varying from the most decomposed layer located just above the soil surface, where microbial activity is greatest, to the least decomposed layer located in the most superficial portion.

Thus, the aim of this study was to assess the effects of straw decomposition degree on leaching potential and weed (Ipomoea grandifolia) control efficacy using tebuthiuron and hexazinone in green sugarcane harvesting system.

\section{MATERIAL AND METHODS}

Leaching was carried out with adaptations to the protocol of the Organization for Economic Cooperation and Development (OECD, 2004), developed to study pesticides in soil columns (deformed samples).

\section{Herbicides}

\section{Leaching}

The analytical standards and radiolabeled forms $\left({ }^{14} \mathrm{C}\right.$-ring labeled) of tebuthiuron (specific activity $=3.01 \mathrm{MBq} \mathrm{mg}^{-1}$ and purity $>98 \%$ ) and hexazinone (specific activity $=3.14 \mathrm{MBq} \mathrm{mg}^{-1}$ and purity $>98 \%$ ) were applied at rates of 1.000 and $500 \mathrm{~g}$ i.a. ha $\mathrm{h}^{-1}$, respectively, corresponding to the maximum doses recommended for the field, regardless of soil type.

\section{Weed control efficacy}

Herbicides efficacy was evaluated in pots containing commercial formulations: Combine $500 \mathrm{SC}$ (tebuthiuron) and Broker $750 \mathrm{WG}$ (hexazinone), on the 900 and 187.5 g i.a. ha ${ }^{-1}$ rates, respectively. Rates differ in the two tests since leaching was tested with the maximum application rate, regardless of soil type OECD (2004), whereas weed control efficacy followed manufacturer's recommendations.

\section{Soil}

A sample from the surface layer $(0-20 \mathrm{~cm})$ of a Red-Yellow Latosol (LVA) (Embrapa, 2006), located at $22^{\circ} 40^{\prime} 20^{\prime \prime} \mathrm{S}$ and $47^{\circ} 37^{\prime} 31^{\prime \prime} \mathrm{W}$, was collected because it is very representative of sugarcane areas. Soil samples were air dried, sieved in a $2 \mathrm{~mm}$ mesh and stored under room temperature. Particle size analysis was performed using the hydrometer method. The $\mathrm{pH}$ was determined in $\mathrm{CaCl}_{2} 0.01 \mathrm{~mol} \mathrm{~L}^{-1}$, with soil: solution ratio of $1: 2.5$. The chemical analyzes were performed according Raij \& Quaggio, 1983. The soil presented the following chemical and physical properties: $\mathrm{pH}\left(\mathrm{CaCl}_{2}\right)$ $=4.5$; organic matter $=14 \mathrm{~g} \mathrm{dm}^{-3}$; phosphorous $=3 \mathrm{mg} \mathrm{dm}{ }^{-3} ;$ potassium $=0.7$, calcium $=5$, magnesium $=2$, aluminum $=3, \mathrm{H}+\mathrm{Al}=11$, sum of bases $=7.7$ and CEC $=18.7 \mathrm{mmol}_{\mathrm{c}} \mathrm{dm}^{-3}$; base saturation $=41 \%$; sand $=756$, silt $=18$, and clay $=226 \mathrm{~g} \mathrm{~kg}^{-1}$.

\section{Straw}

Sugarcane straw samples (variety SP 90-3414) were collected after the mechanical harvest of the third-ratoon crop, dried in stove at $65^{\circ} \mathrm{C}$ until constant weight and cut into 
pieces of approximately $2.5 \mathrm{~cm}$ for the leaching experiment. These samples differed in their degree of decomposition: "straw 1" has the lowest degree of decomposition (found in the upper layer); "straw 2" has intermediate degree of decomposition; and "straw 3" has the greatest degree of decomposition (directly touching the ground). "straw 4" is the mixture of the other three straws (at the same mass ratio), as a way to simulate the same configuration found in the field. The chemical and physical properties of straws were determined according Alcarde (2009) (Table 1).

\section{Leaching}

The experimental design was completely randomized with five treatments (four types of straw +1 control with no straw), two herbicides (tebuthiuron and hexazinone) and three replications, totalizing 30 plots (columns).

Glass column (length $=30 \mathrm{~cm}$, diameter $=$ $5 \mathrm{~cm}$, and conical lower end) were used for packing of soil. Fiberglass and $\mathrm{HCl}$ sterilized sand were added to the conical part, serving as an inert support. Soil packaging was made manually to a height of $20 \mathrm{~cm}$, with a density of $\sim 1.78 \mathrm{~g} \mathrm{~cm}^{-3}$. Straw samples of $11.0 \mathrm{~g}$ were added to the soil surface and packed at density of $0.08 \mathrm{~g} \mathrm{~cm}^{-3}$, which corresponds to a layer of $7 \mathrm{~cm}$ of straw. A thin layer of glass wool was placed at the top to promote the homogeneous water dispersion and avoid surface disturbance. The soil columns were then saturated by capillarity with $\mathrm{CaCl}_{2}$ $0.005 \mathrm{~mol} \mathrm{~L}^{-1}$ for $\sim 2 \mathrm{~h}$. Then, water excess was drained gravimetrically. Soon after, aliquots of $200 \mu \mathrm{L}$ from solutions in concentrations of $981.5 \mu \mathrm{g} \mathrm{mL}^{-1}$ for tebuthiuron and $498.1 \mu \mathrm{g} \mathrm{mL}^{-1}$ for hexazinone, both with radioactivities of 58.3 $\mathrm{Bq} \mathrm{mL}^{-1}$, were applied to the columns to

Table 1 - Chemical and physical properties of straws

\begin{tabular}{|c|c|c|c|c|c|}
\hline \multirow{2}{*}{ Straw } & $\mathrm{pH}$ & $\mathrm{C} / \mathrm{N}$ & $\mathrm{CTC}$ & Density & CRA \\
\cline { 2 - 6 } & $\left(\mathrm{CaCl}_{2}\right)$ & & $\left(\mathrm{mmol}_{\mathrm{c}} \mathrm{kg}^{-1}\right)$ & $\left(\mathrm{g} \mathrm{dm}^{-3}\right)$ & $(\%)$ \\
\hline 1 & 5.8 & $53 / 1$ & 320 & 0.08 & 220 \\
\hline 2 & 5.9 & $34 / 1$ & 350 & 0.08 & 215 \\
\hline 3 & 5.9 & $28 / 1$ & 400 & 0.08 & 165 \\
\hline
\end{tabular}

$\mathrm{CTC}=$ capacity of cation exchange; $\mathrm{CRA}=$ capacity of water retention. reach the recommended field rates (1.000 and $500 \mathrm{~g}$ i.a. ha ${ }^{-1}$, respectively). The columns were placed in a darkened room at $25 \pm 2{ }^{\circ} \mathrm{C}$. Rainfall was simulated in two stages ( 6 and $30 \mathrm{~h}$ after herbicide application) applying 50 $\mathrm{mm}$ of $\mathrm{CaCl}_{2} 0.005 \mathrm{~mol} \mathrm{~L}^{-1}$ solution with the aid of a peristaltic pump with continuous flow for two hours, totalizing $100 \mathrm{~mm}$ of rain. The leachate was collected immediately after the simulations, and aliquots of $10 \mathrm{~mL}$ were analyzed by liquid scintillation counting (LSC). After $48 \mathrm{~h}$, soil samples were taken from the inside of the columns with the aid of pressurized air into sections of $2.5 \mathrm{~cm}$ (for the first two layers of soil) and then into sections of $5 \mathrm{~cm}$, and placed in aluminum containers, air-dried, grinded and mixed for further oxidation of subsamples $(0.2 \mathrm{~g}$ for soil and $0.10 \mathrm{~g}$ for straw) in a biological oxidizer $\left(900{ }^{\circ} \mathrm{C}\right.$ for $\left.3 \mathrm{~min}\right)$ in triplicate. In order to do so, the ${ }^{14} \mathrm{CO}_{2}$ released was captured by the monoethanolamine solution, and radioactivity was determined through LSC. The straw layer was removed separately. The recovery of radioactivity ranged from 90 to $110 \%$, which is consistent with that suggested by the OECD (2004).

\section{Weed control efficacy}

The experimental design was completely randomized with four types of straw, two herbicides (tebuthiuron and hexazinone) and four replications, in addition to 16 control groups (with no herbicide application), totaling 48 plots. The experiment was conducted outdoors in order to simulate natural conditions for plant development. Fertilization was based on soil chemical analysis in order to improve weeds germination. Next, soil samples were placed in 10-liter pots and germinated with 100 seeds of Ipomoea grandifolia per pot (Little Bell). Soil moisture was maintained at $70 \%$ of field capacity, by gravimetry.

Straw (variety SP 90-3414) was applied at a rate of $16 \mathrm{t}$ of straw ha-1 (or $82 \mathrm{~kg} \mathrm{~m}^{-3}$ of straw) based on field measurements considering a central band of $20 \mathrm{~cm}$ between rows with height of $7 \mathrm{~cm}$, and $60 \%$ of humidity. This straw band is thicker and therefore considered optimal for observing herbicide transposition since it is able to promote retain the entire 
amount of herbicide sprayed (Velini \& Negrisoli, 2000; Medeiros et al., 2002; Veiga Filho et al., 2002). The spraying of herbicides was achieved using manual pump with a maximum pressure of $200 \mathrm{lbf} \mathrm{pol}^{-2}$ in an area of $12 \mathrm{~m}^{2}$. The nozzle used was array type (model $110015 \mathrm{JSF}$ ) spaced at $55 \mathrm{~cm}$ and positioned at $0.5 \mathrm{~m}$ height from the surface. The system was operated at a constant speed of $1.74 \mathrm{~km} \mathrm{~h}^{-1}$ for tebuthiuron and of 1.30 $\mathrm{km} \mathrm{h}^{-1}$ for hexazinone, which corresponded to spray volumes of 300 and $400 \mathrm{~L} \mathrm{ha}^{-1}$, respectively. A pressure regulator with 1.5 bars was used and operated at $0.48 \mathrm{~L} \mathrm{~min}^{-1}$ to maintain flow and droplets uniformity.

Visual evaluations of weed control were conducted at 7, 14, 21 and $28 \mathrm{~d}$ after application (DAA). Results were subjected to analysis of variance by $\mathrm{F}$ test, and their means were compared by Scott \& Knot (1974), at $5 \%$ of probability $(\mathrm{p}<0.05)$.

\section{RESULTS AND DISCUSSION}

\section{Leaching}

Regardless of their degree of decomposition, the presence of straw on the soil surface affected herbicides leaching potential. When straw was used, on average, about $3 \%$ of tebuthiuron and $5 \%$ of hexazinone were leached after $100 \mathrm{~mm}$ of rain simulation. In its absence, the leaching corresponded to 5 and $37 \%$, respectively. This result confirms the greater leaching potential of hexazinone compared to tebuthiuron (USPAEPA, 1994; Calderon et al., 2004; Queiroz et al., 2009).

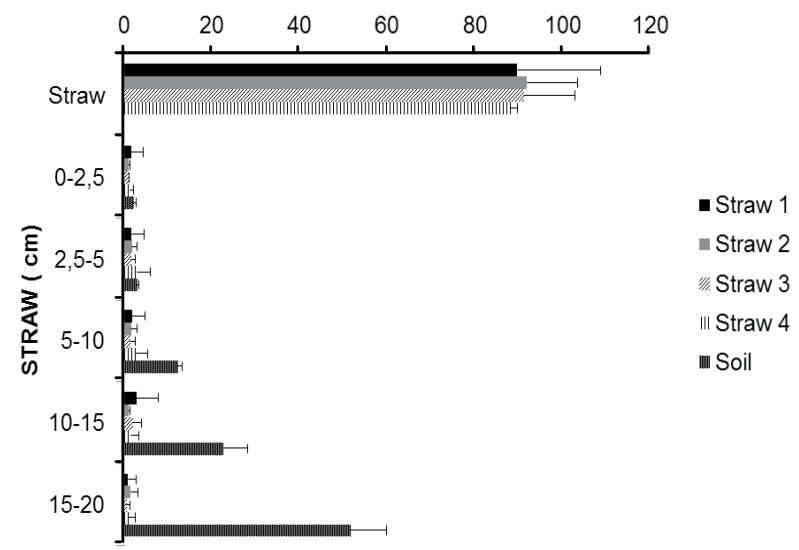

Figure 1 - Percentages of tebuthiuron residue retained in the straw and in the soil profile.

Planta Daninha, Viçosa-MG, v. 32, n. 4, p. 809-815, 2014
On average, 85 and $78 \%$ of the applied amounts of tebuthiuron and hexazinone, respectively, were retained in the straw, regardless of their degree of decomposition (Figures 1 and 2 ). The high retention of herbicides in straw seems to be related to a physical trapping phenomenon, since all types of straw tested, regardless of the decomposition degree, has high water retention capacity. Straw in quantities over $5 \mathrm{t} \mathrm{ha}^{-1}$ can intercept virtually all tebuthiuron applied, with transpositions below 10\% (Velini et al., 2009). However, about $50 \%$ of tebuthiuron transposed the straw layer after simulating $65 \mathrm{~mm}$ of rain, which could affect its residual effect and compromise weed control. The much lower transposition in our experiment $(<15 \%$ for tebuthiuron and $<22 \%$ for hexazinone) can be explained, at least in part, by artifacts of the methodology adopted that was developed for soils. The straw, unlike soils, presents enormous amount of macropores that favors water preferential flow without necessarily arresting the herbicide when the rain is simulated in a single point (i.e., with a single flow channel), underestimating its transposition.

After reaching the soil, both herbicides showed great mobility in the soil profile (Figures 1 and 2). Previous studies have identified tebuthiuron in groundwater (Nicolella et al., 1999; Duarte, 2003; Pessoa et al., 2003) and in deeper soil layers (up to $53 \mathrm{~m}$ depth after four years of applications, at concentrations of $0.08 \mu \mathrm{g} \mathrm{kg}{ }^{1}$ ) (Gomes et al., 2001), raising concern about its potential of groundwater contamination.

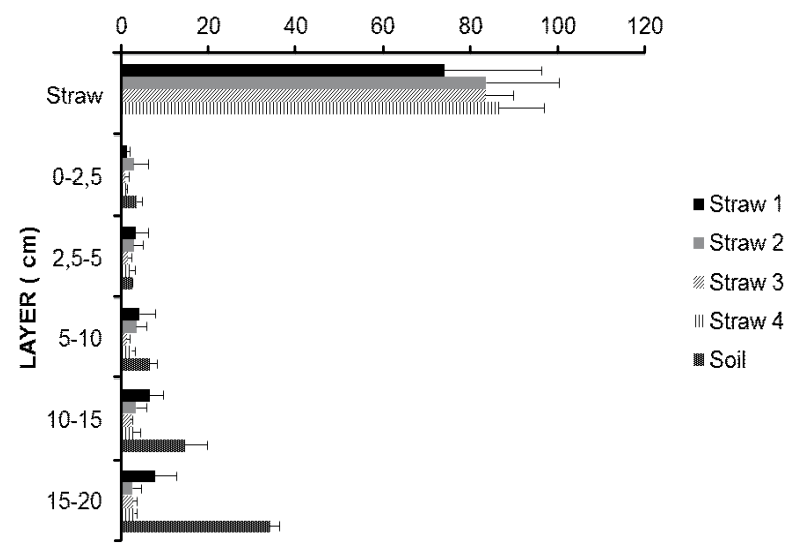

Figure 2 - Percentages of hexazinone residues retained in the straw in the soil profile. 


\section{Experiment effectiveness of control}

Symptoms of intoxication were observed $7 \mathrm{~d}$ after application (DAA), but only at 28 DAA were found 84 and $98 \%$ of control for higher efficacy treatments with hexazinone and tebuthiuron, respectively (Figures 3 and 4). In general, tebuthiuron showed higher efficacy than hexazinone. Furthermore, the straw decomposition affected control efficacy of Ipomoea grandifolia by hexazinone (Figure 3), but not by tebuthiuron (Figure 4). The straw 1 (less decomposed) showed the worse $(30 \%$ of control) and straw 4 (all the straws together) the best ( $84 \%$ of control) weed control for hexazinone (Figure 3).

About $48 \mathrm{~h}$ after seeding rained $42.5 \mathrm{~mm}$ for nearly $1 \mathrm{~h}$, which corresponded to $2.2 \mathrm{~L}$ of water per pot. For comparison, the soil water volume at field capacity corresponds to $1.14 \mathrm{~L}$ and the hydraulic conductivity of sandy soils similar to ours corresponds to $0.2 \mathrm{~m} \mathrm{~h}^{-1}$. Furthermore, the accumulated precipitation volume corresponded to $123.3 \mathrm{~mm}$ up to $7 \mathrm{DAA}$, which should have favored mainly hexazinone leaching due to its higher solubility, thus decreasing its weed control efficacy. It is easier for highly soluble herbicides to cross the straw layer and therefore they have greater potential for leaching (Strek \& Weber, 1982, Rodrigues et al., 1993). This behavior is strongly influenced by the intensity and volume of rain, as well as its timing

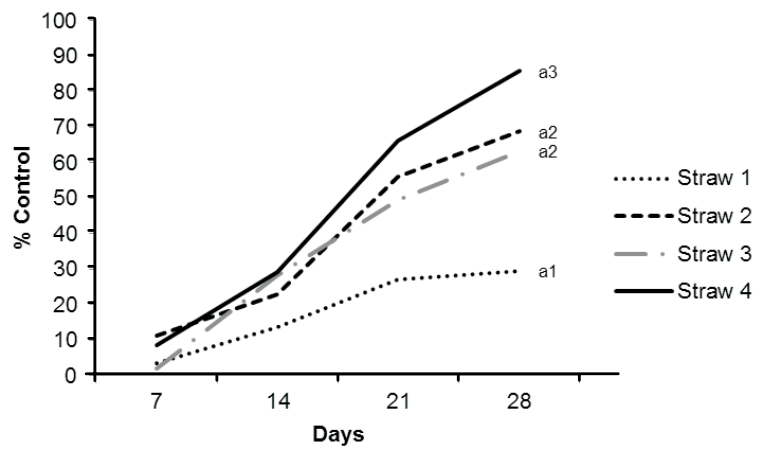

For the last period (28 DAA), letters with different numbers differ statistically (Scott \& Knot, p < 0.05).

Figure 3 - Effect of the straw decomposition degree on the percentage of control of Ipomoea grandifolia by hexazinone, assessed up to 28 days after application (DAA). after application (Rodrigues et al., 1993; Vellini et al., 2009), besides other factors. For tebuthiuron, the residence time (Vellini et al., 2009) and the straw amounts (Rossi et al., 2013) turned difficult its transfer to the soil, regardless of the simulated rainfall amounts.

Photolysis appears to be a major mechanism of herbicide dissipation in systems where the straw is maintained on soil surface (Vellini, personal communication), which may have contributed to the low hexazinone efficacy. In addition, the higher temperature of the straw (in relation to the soil) due to its decomposition processes should contribute to greater volatilization. The surface temperatures of the least (straw 1) and most (straw 3) decomposed straws were 58.3 and $42.5{ }^{\circ} \mathrm{C}$, respectively, which could explain the lower control effectiveness of straw 1 . Moreover, these straws are able to absorb 220 and $165 \%$ of water, respectively (Table 1 ). The ambient temperature ranged from 19.5 to $28.9^{\circ} \mathrm{C}$ whereas the relative humidity ranged from 30 to $99 \%$ during $28 \mathrm{~d}$ of the experiment (Figure 5), which should cause high vapor pressure deficit in certain periods of the day and thus favor volatilization, particularly in the least decomposed straw (straw 1). The effect of temperature on the rate of dissipation of the herbicide may not be overlooked. For example, the hexazinone half-lives decreased from 180 to $21 \mathrm{~d}$ when temperature increased from 20 to $50{ }^{\circ} \mathrm{C}$. Therefore, part significant of

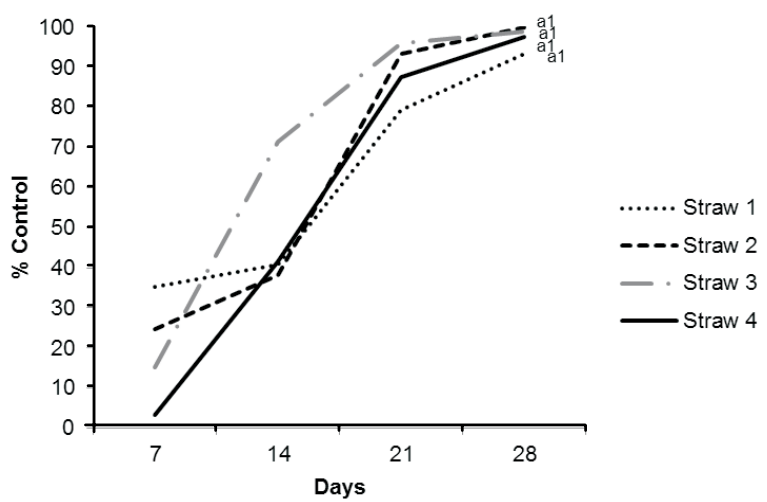

For the last period (28 DAA), letters with different numbers differ statistically (Scott \& Knot, p < 0.05).

Figure 4 - Effect of the straw decomposition degree on the percentage of control of Ipomoea grandifolia by tebuthiuron, assessed up to 28 days after application (DAA). 


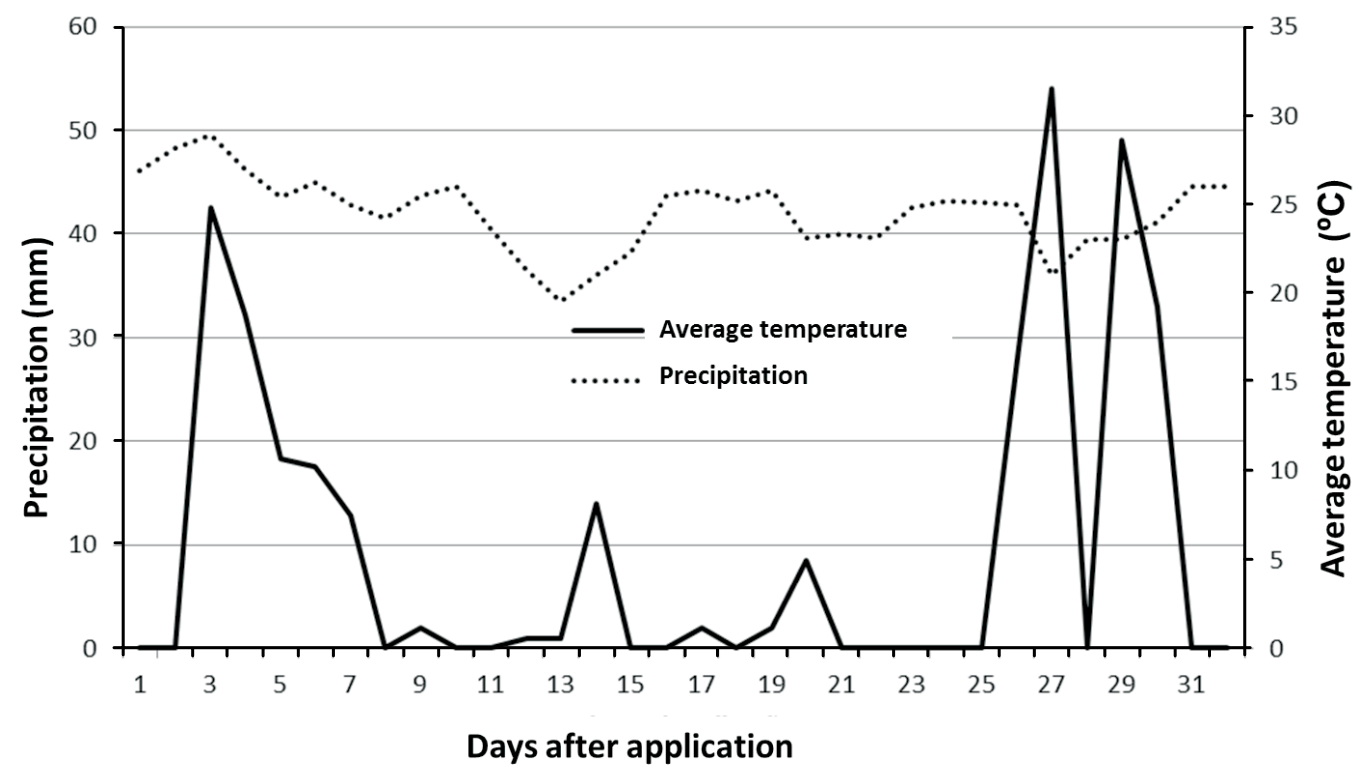

Figure 5 - Changes in relative to temperature and rainfall 31 days after application.

hexazinone retained in the least decomposed straw may have dissipated, having its efficacy compromised.

Tebuthiuron also has high solubility, but 13 times lower than that of hexazinone. Thus, the rainfall events combined with molecule attributes may not have been enough to leach it to depths where weed control is compromised. In addition, tebuthiuron has slower dissipation and higher sorption than hexazinone. Therefore, its amounts left in the straw or in the soil surface should be enough to control weeds until 28 DAA. Negrisol \& Vellini (2007) also reported that tebuthiuron was able to control Ipomoea grandifolia in $100 \%$ at 28 DAA. Despite the success of all treatments, the application of tebuthiuron in the most decomposed straw (straw 3) favored weed control, probably due to its lower water retention capacity (Table 1) that favors herbicide transposition through the straw.

Tebuthiuron is classified as non-volatile at $25^{\circ} \mathrm{C}$, but it may undergo volatilization when applied to straw at $50{ }^{\circ} \mathrm{C}$, in addition to photolysis when used in green sugarcane harvesting systems. However, there are no reports supporting these hypotheses. Our results emphasize that tebuthiuron losses by volatilization, leaching, and dissipation were not enough to compromise weed control, despite the large rainfall volumes $(235.8 \mathrm{~mm}$ up to 28 DAA) and high temperatures (Figure 5), typical of tropical regions.

Straw presence decreased herbicide leaching, especially for hexazinone. The degree of straw decomposition had little influence on leaching, but affected weed control efficacy mainly for hexazinone. Our results are preliminary, but clearly indicate the need evaluate volatilization and photolysis effects on herbicides dissipation in order to clarify the dynamics of these compounds in the green sugarcane harvesting system.

\section{LITERATURE CITED}

ALCARDE, J. C. Metodologia official de análise de corretivo de acidez. 3.ed. Porto Alegre, 2009, 58 p.

CALDERÓN, M. J. et al. Hexazinona and simazine dissipation in forestry field nurseries. Chemosphere, v. 54, n. 1, p. 1-8, 2004.

CAVENAGHI, A. L. Dinamica do herbicida amicarbazone (DinamicR) aplicado sobre palha de cana-de-acucar (Saccharum officinarum). Planta Daninha, v. 25, n. 4, p. 831-837, 2007.

CEDDIA, M. B. et al. Sistemas de colheita da cana-de-açúcar e alterações nas propriedades físicas de um solo Podzólico amarelo no Estado do Espírito Santo. Pesq. Agropec. Bras., v. 34, p. 1467-1473, 1999. 
COMPANHIA NACIONAL DE ABASTECIMENTO CONAB. Safra 2013/2014: segundo levantamento. Brasília, 2014. Available in: <http://www.conab.gov.br/ conteudos. php? a=1253\&t=>. Acesso em: 5 ago. 2014.

DUARTE, N. F. Potenciais impactos ambientais da monocultura da cana-de-açúcar. In: VALADÃO, R. C.; LANDAU, E. C. (Ed.). Análise integrada do meio ambiente. Belo Horizonte: UFMG/PMLP, 2003. CD ROM.

EMPRESA BRASILEIRA DE PESQUISA AGROPECUÁRIA - EMBRAPA. Centro Nacional e Pesquisa em Solos. Sistema brasileiro de classificação de solos. Brasilia: Embrapa, SPI; Rio de Janeiro: Embrapa Solos, 2006. 306 p.

GOMES, M. A. F. et al. Ocorrência do herbicida tebuthiuron na água subterrânea na Microbacia do Córrego Espraiado, Ribeirão Preto-SP. Pestic. R. Ecotoxicol. Meio Amb., v. 11, n. 4, p. 65-76, 2001.

\section{INSTITUTO BRASILEIRO DE GEOGRAFIA E} ESTATÍSTICA - IBGE. Levantamento sistemático da produção. Rio de Janeiro, 2014. Available in: < http:// www.sidra.ibge.gov.br/>. Acesso em : 21 jan. 2014.

MACIEL, C. D. G. Eficiencia e seletividade dos herbicidas trifloxysulfuron-sodium + ametryne e hexazinona + diuron em funcao da tecnologia de aplicação e do manejo mecanico da palha de cana-de-açúcar na linha de plantio. Planta Daninha, v. 26, n. 3, p. 665-676, 2008.

MACIEL, C. D. G. et al. Simulação do caminhamento da água da chuva e herbicidas em palhas utilizadas em sistemas de plantio direto. Planta Daninha, v. 23, n. 8, p. 471-481, 2005.

MEDEIROS, D. et al. Efeito da intensidade de chuva e da quantidade de palha de cana-de-açúcar sobre a eficácia de herbicidas. In: CONGRESSO BRASILEIRO DA CIÊNCIA DAS PLANTAS DANINHAS, 23., 2002,

Gramado. Anais... Londrina: IAPAR, 2002. p. 510.

MENDOZA, H. N. S. et al. Propriedades químicas e biológicas de solo de tabuleiro cultivado com cana-de-açúcar com e sem queima da palha. R. Bras. Ci. Solo, v. 24, n. 5, p. 201-207, 2000.

NICOLELLA, G. Avaliação do risco de contaminação do lençol freático, pelo herbicida tebuthiuron em cultura de cana-de-açúcar, utilizando geoestatística e simulador CMLS. 1999. 163 f. Tese (Doutorado em Engenharia Agrícola) - Universidade Estadual de Campinas, Capinas-SP, 1999.

ORGANIZATION FOR ECONOMIC CO-OPERATION AND DEVELOPMENT - OECD. Guideline test 106: desorption using a batch equilibrium method. Paris: 2004. 44 p.
PESSOA, M. C. P. Y. et al. Identificação de áreas de exposição ao risco de contaminação de águas subterrâneas pelos herbicidas atrazina, diuron e tebuthiuron. Pestic. Ecotoxicol. Meio Amb., v. 13, n. 8, p. 111-122, 2003.

PINHEIRO, E. F. M. et al. Impact of pre-harvest burning versus trash conservation on soil carbon and nitrogen stocks on a sugarcane plantation in the Brazilian Atlantic forest region. Plant Soil, v. 333, n. 6, p. 71-80, 2010.

QUEIROZ, S. C. N. et al. Comportamento do herbicida hexazinona em área de recarga do aqüífero Guarani cultivada com cana-de-açúcar. Química Nova, v. 32, n. 2, p. 378-381, 2009.

RAIJ, B. van; QUAGGIO, J. A. Métodos de análise de solo para fins de fertilidade. Campinas: Instituto Agronômico de Campinas, 1983. 31 p. (Boletim Técnico, 81)

RODRIGUES, B. N. Influência da cobertura morta no comportamento dos herbicidas imazaquin e clomazone. Planta Daninha, v. 11, n. 1, p. 21-28, 1993.

ROSSI, C. V. S. et al. Dinâmica do herbicida metribuzin aplicado sobre palha de cana-de-açúcar (Saccarum officinarum). Planta Daninha, v. 31, n. 5, p. 223-230, 2013.

SCOTT, A.; KNOTT, M. Cluster-analysis method for grouping means in analysis of variance. Biometrics, v. 30, n. 3, p. 507-512, 1974.

STREK, H. J.; WEBER, J. B. Adsorption, mobility and activity comparisons between alachlor (Lasso) and metolachlor (Dual). Proc. Southern Weed Sci. Soc., v. 35, n. 7, p. 332-338, 1982.

UNIÃO DA INDÚSTRIA DE CANA-DE-AÇÚCAR ÚNICA. Folder institucional. São Paulo, 2011. Available in: $<$ http://www.unica.com.br/content/show.asp?cnt Code $=\{$ BEE1 06FF-D0D54264B1B37E0C7D4031D6 $\}>$ http://www.unica.com.br/ userFiles/ Protocolo_Assinado_ Agro ambiental.pdf. $>$. Accessed on: 14 nov. 2013 .

UESPA. Guideline test 312:leaching in soils columns. 2004. Paris $15 \mathrm{p}$.

VEIGA FILHO, A. Evolução da mecanização do corte da cana-de-açúcar em São Paulo. In: CONGRESSO NACIONAL DA STAB, 8., 2002, Recife. Anais... Recife: 2002. p. 515-521.

VELINI, E. D.; NEGRISOLI, E. Controle de plantas daninhas em cana crua. In: CONGRESSO BRASILEIRO DA CIÊNCIA DAS PLANTAS DANINHAS, 22., 2000, Foz de Iguaçu. Palestras. Foz de Iguaçu: Sociedade Brasileira da Ciência das Plantas Daninhas, 2000. p. 148-164.

VELINI, E. D. et al. Dinâmica do tebuthiuron em palha de canade-açúcar. Planta Daninha, v. 27, n. 4, p. 815-821, 2009.

Planta Daninha, Viçosa-MG, v. 32, n. 4, p. 809-815, 2014 